\title{
Evidence of genetic and phenotypic heterogeneity in the Romano-Ward syndrome
}

\author{
J C S Dean, S Cross, K Jennings
}

\begin{abstract}
We report two families with phenotypically different forms of Romano-Ward syndrome. In one family, only five of 18 affected subjects are symptomatic, whereas in the other the proportion is three out of five. The families show distinct ECG morphologies, in addition to QT prolongation. Previous reports have shown genetic linkage either to the HLA locus on chromosome 6 or the Harveyras oncogene on chromosome 11 . No linkage was found to either locus in the families reported here. The implications of phenotypic and genotypic heterogeneity in Romano-Ward syndrome are discussed in relation to the neurogenic and intrinsic models of pathogenesis. (f Med Genet 1993;30:947-50)
\end{abstract}

Persons with Romano-Ward syndrome are at risk for syncope or near syncope, pseudoepileptic seizures, and sudden death associated with ventricular arrhythmia. Episodes of arrhythmia are commonly precipitated by emotional stress (particularly sudden stress) or physical exertion. ${ }^{12}$ Ventricular repolarisation anomalies (prolonged QT interval, abnormal $T / U$ wave morphology) are found on the resting ECG. The disorder is inherited as an autosomal dominant and while early family studies suggested a gene locus on chromosome

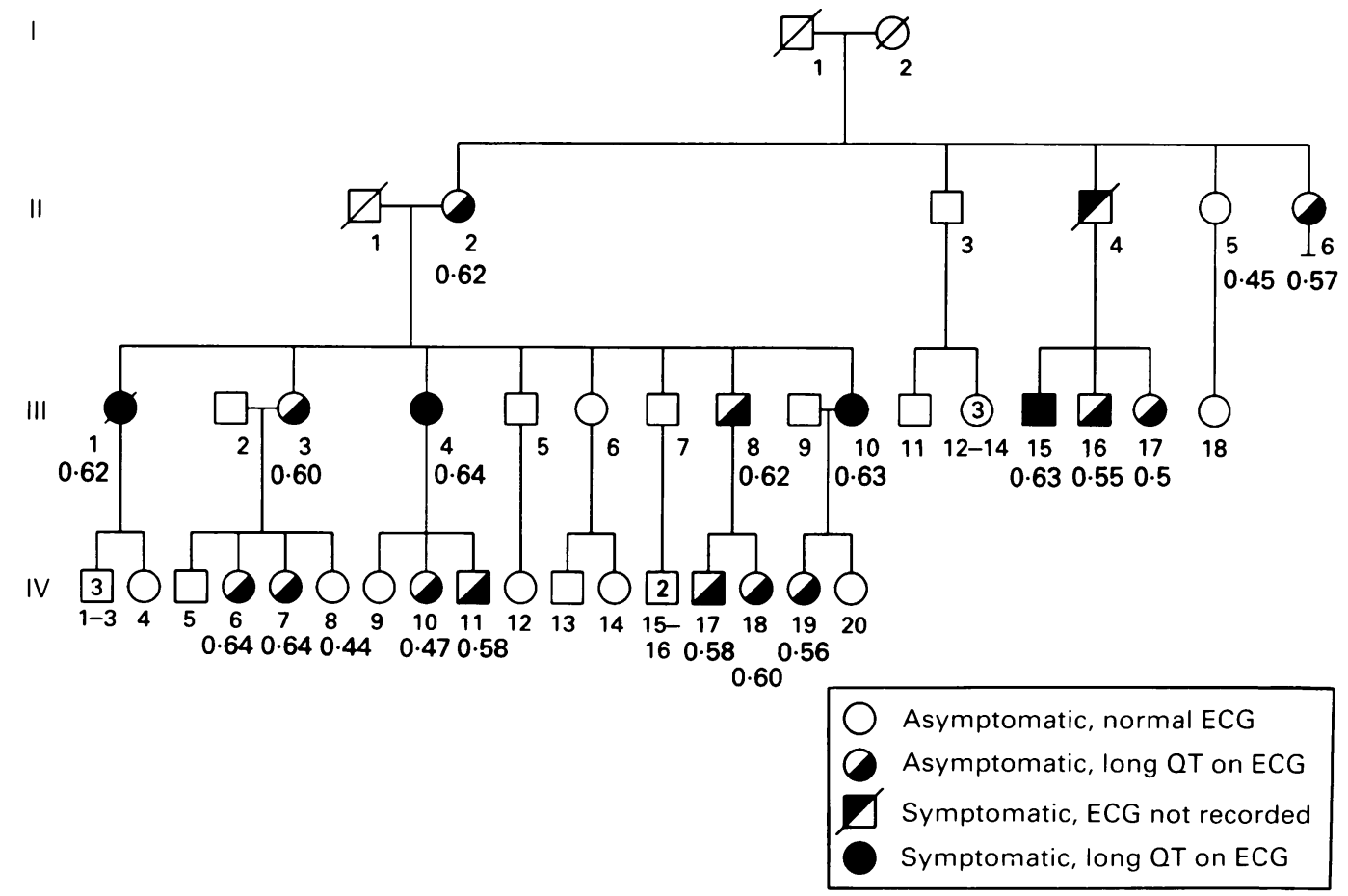

Figure 1 Pedigree of family 1. The status of persons in generation $I$ is unknown as they were dead at the time of the

6 near the HLA region, ${ }^{34}$ other families appeared unlinked. ${ }^{5}$ Linkage shown to the Harvey-ras oncogene on chromosome 11 in some families ${ }^{6}$ has reopened the debate on pathophysiology ${ }^{7}$ (neurogenic or intrinsic to the myocardium). We present studies of two families with Romano-Ward syndrome, showing no linkage to either locus and providing evidence for further phenotypic and genetic heterogeneity in this disorder.

\section{Family reports}

A detailed description of the cardiological findings in these families has been published elsewhere. ${ }^{8}$

\section{FAMILY 1}

Five of 18 affected subjects in this family are or have been symptomatic (fig 1 ). II.4 is reported to have sustained a seizure after a sudden fright at the age of 6 years. He died from malignancy before this study and no ECG is available. III 1 died suddenly at the age of 46 from a presumed arrhythmia shortly after diagnosis (necropsy showed no other cause of death). III 4 developed infrequent 'seizures' at the age of 38 years (EEG and cranial CT scan were normal). Ambulatory ECG taken while asymptomatic showed short runs of ventricular bigeminy. Beta blockade abolished her study. QTC is shown for key subjects.
Department of Medical Genetics, Medical School, Aberdeen Royal Hospitals NHS Trust, Foresterhill,

Aberdeen AB9 2ZB,

J C S Dean

Cardiac Department, Aberdeen Royal

Hospitals NHS Trust,

Foresterhill,

Aberdeen AB9 2ZB,

UK.

$S$ Cross

$\mathrm{K}$ Jennings

Correspondence to Dr Dean.

Received 7 April 1993.

Revised version accepted

17 June 1993 

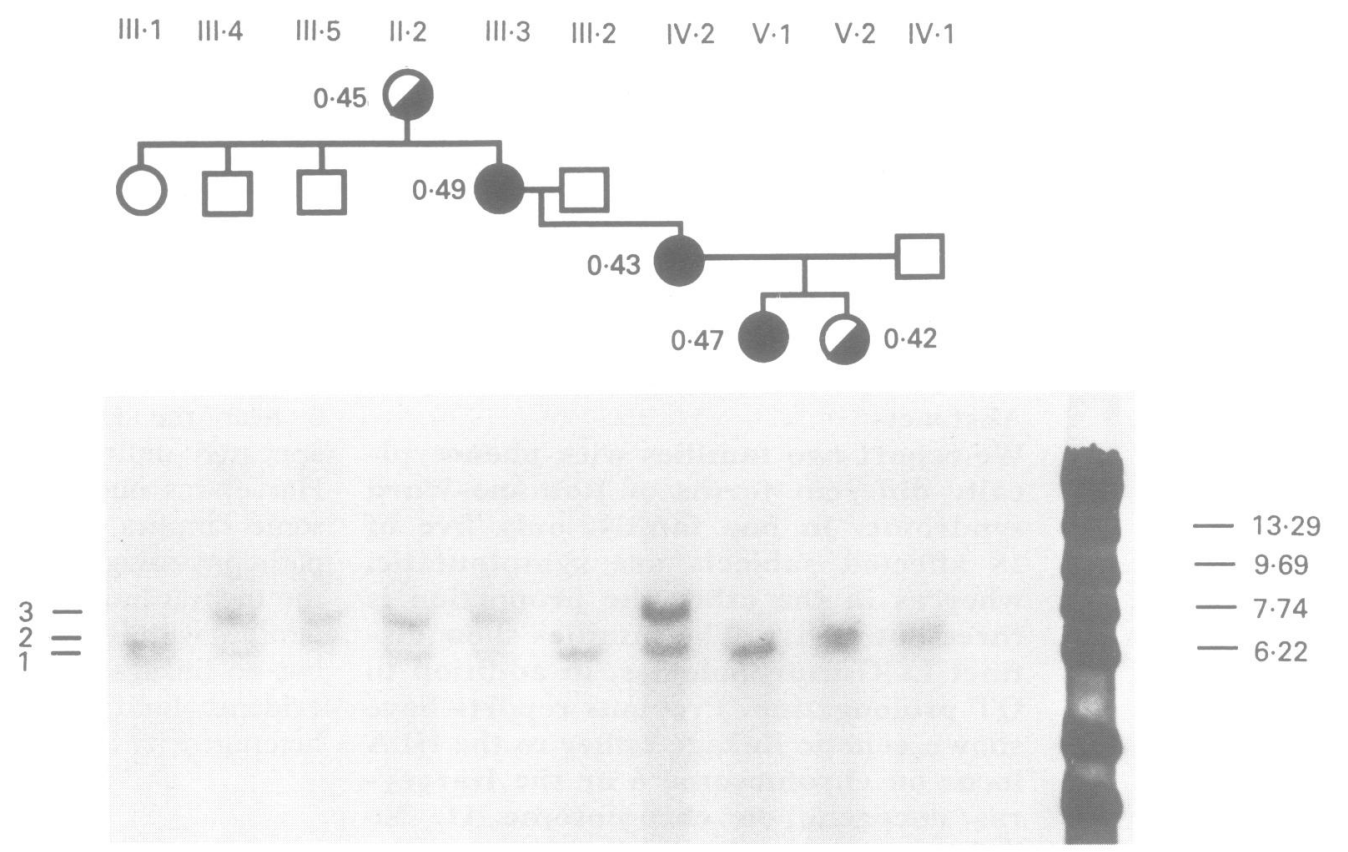

DNA

marker (kb)

Figure 2 Pedigree and autoradiograph from family 2. Pedigree symbols are as for fig 1, with QTc shown for key subjects. After digestion with BamHI and Southern blotting, genomic DNA from family 2 has been probed with pUCEF6.6.

symptoms. III $10 \mathrm{had}$ a single seizure at the age of 32 during a severe exacerbation of duodenal ulcer disease associated with hypokalaemia (serum potassium $2 \cdot 4 \mathrm{mmol} / \mathrm{l}$ ). She has been asymptomatic on a $\beta$ blocker for 3 years. III 15 (now aged 32) had one syncopal attack after two episodes of near syncope at the age of 18 years associated with severe physical stress.

\section{FAMILY 2}

Three out of five affected subjects in this family are symptomatic (fig 2), arrhythmias occurring with no clear emotional or physical precipitants. V· 1 was found to have an irregular pulse at the age of 11 during a routine medical examination, and non-sustaining polymorphic VT was documented. Episodic near syncope and exertional dyspnoea were reported. Treatment with a permanent pacemaker has abolished symptoms and arrhythmias, after unsuccessful $\beta$ blockade and left cervical sympathectomy. Her mother, IV 2 , developed 'seizures' at 31 years (EEG and cranial CT scan normal), which were apparently suppressed by phenytoin. Reinvestiga-
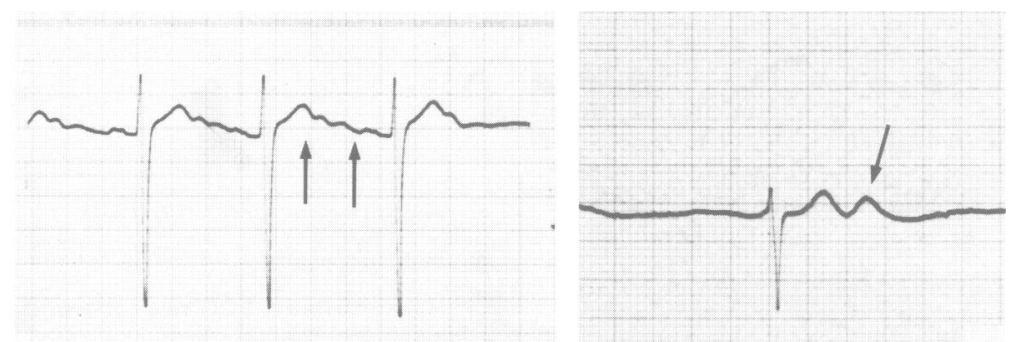

Figure 3 (Left) ECG lead V2 from subject III·15, family 1. Note prolonged $Q T$ interval with slurred $T / U$ wave (between arrows). (Right) ECG lead $V 3$ from subject $V \cdot 1$, family 2 . Note prolonged $Q T$ interval with prominent $U$ wave (arrowed). tion when her daughter was diagnosed showed episodic polymorphic VT without syncope or seizure. Arrhythmia was suppressed by $\beta$ blockade with a permanent pacemaker. Her mother, III·3, had two episodes of syncope at the age of 61 , one with proven VT. The arrhythmia was attributed to myocardial ischaemia and she is asymptomatic on propafenone.

\section{Electrocardiography}

Standard resting 12 lead ECGs were recorded. The QT interval was measured to the point of return to the isoelectric line in one of leads V2V4. ${ }^{9}$ QTc was calculated by Bazett's formula and was considered prolonged if greater than 0.44 seconds. In family 1 , all affected subjects have long QTc with notched or bifid $T$ waves (fig 3), and two have $T$ wave inversion in V1-3 also. Two asymptomatic subjects (II.5 and IV.8) were excluded from the linkage analysis because, despite borderline increased QTc, T wave morphology was normal. In family 2 , affected subjects have tall $U$ waves with heights greater than $25 \%$ of the $\mathrm{T}$ wave (fig 3 ). Two affected subjects, IV.2 and V·2, had a normal QTc, but abnormal $\mathrm{T} / \mathrm{U}$ wave morphology, and one of these (IV.2) has been symptomatic with ventricular tachycardia. Affected members of long QT families with normal QTcs have been previously documented. ${ }^{10}$ Other affected subjects in family 2 had long QTc and abnormal morphology.

\section{Genotyping}

HLA class I typing was carried out by a modified NIH lymphocytotoxic technique using two colour fluorescein staining. Genomic DNA was extracted from lymphocytes 
using standard methods and $5 \mu \mathrm{g}$ digested using the appropriate restriction endonuclease. DNA fragments were separated by $1 \%$ agarose gel electrophoresis and transferred to a Hybond $\mathrm{N}+$ nylon membrane by Southern blotting. The probes were labelled with ${ }^{32} \mathrm{P}$ dCTP by random oligonucleotide primed synthesis (Amersham UK). Hybridisation conditions were as described by the manufacturers. DNA polymorphisms at the H-ras oncogene were identified using the probe/enzyme combination pUCEJ6.6/Bam $\mathrm{HI}^{11}$ and at a closely linked locus 363 bp $5^{\prime}$ to the human insulin gene (INS) using pHINS310/PvuII. ${ }^{12}$ HLA haplotypes were assigned using Ott's method $^{13}$ and data was analysed using LINKAGE V.

\section{Results}

No evidence of linkage of Romano-Ward syndrome was found either to the HLA locus or to the Harvey-ras/insulin gene region of chromosome 11 in either family (table). This remained true even when apparently unaffected subjects (possible non-penetrant gene carriers) were excluded (data not shown).

\section{Discussion}

CLINICAL HETEROGENEITY

The clinical phenotypes in these two families are distinct, in that in family 1 arrhythmia is unusual and occurs mostly as a consequence of acute 'stress' (for example, illness with hypokalaemia, sudden fright), whereas in family 2 arrhythmia occurs without specific precipitant (although it is sometimes asymptomatic). This is reflected in the proportions of affected persons who are symptomatic in the two families (5/18 in family $1,3 / 5$ in family 2 ). The ECGs are also distinct, family 1 having a prolonged QTc interval (mean 0.59 s) and slurred $\mathrm{T} / \mathrm{U}$ waves, whereas family 2 have a less prolonged QTc interval (mean $0.45 \mathrm{~s}$ ) but abnormal U waves, which are clearly separate from the QT complex. Two of five subjects from family 1 (both asymptomatic) studied by radionuclide ventriculography showed subtle phase abnormalities of right ventricular contraction (delayed spread of a prolonged contraction wave). In family 2 , the three subjects studied had slightly different right ventricular phase abnormalities and also had left ventricular phase and amplitude abnormalities. These findings have been reported in detail elsewhere. ${ }^{8}$ These two families may represent further subtypes of Romano-Ward syndrome, the first with more typical long QT syndrome, ${ }^{9}$ the second with a long QT/abnormal U syn- drome. Other subtypes may exist, as, for example, families have been reported with recurrent polymorphic VT, but normal QTc intervals $^{14} 15$ and with bradycardia dependent long QT syndrome. ${ }^{16}$ The existence of a recessive form of hereditary long QT syndrome, which includes deafness (Jervell Lange-Neilsen syndrome ${ }^{17}$ ), also suggests aetiological heterogeneity. This, coupled with the existence of acquired forms of long QT syndrome, can lead to considerable diagnostic and genetic counselling difficulties. ${ }^{18}$

\section{GENETIC HETEROGENEITY}

In 1982, Itoh $e t a l^{3}$ described a family in which Romano-Ward syndrome was inherited with a particular HLA haplotype. The peak lod score was 2.71 at zero recombination. ${ }^{19}$ Two families investigated subsequently showed weak linkage, ${ }^{4}$ but at least six others did not. ${ }^{5}$ The subjects of this report are also unlinked. Linkage with the Harvey-ras 1 gene on $11 \mathrm{p} 15$ was described initially in one large family (lod score 16.44 at zero recombination), and then in six others, ${ }^{6}$ although the lod scores were less clear cut in four of these. Further 'preliminary' reports suggest that, like the families reported here, a proportion may be unlinked. ${ }^{720}$

Because the arrhythmias may be precipitated by emotional factors and prevented by $\beta$ blockade or left stellate ganglionectomy or both in many Romano-Ward patients, in whom a resting bradycardia is common, the repolarisation anomalies and arrhythmias have been thought to be caused by impaired right sympathetic cardiac innervation. ${ }^{1}$ This 'neurogenic' hypothesis is supported by animal studies. ${ }^{1}$ In the seven families studied by Keating $e t$ $a l,{ }^{6}$ no recombination events were observed between long QT syndrome and the Harveyras 1 gene, leading to its proposal as a possible candidate gene. The Harvey-ras product has $G$ protein functions (including possibly the regulation of potassium conductance, which could cause QT prolongation and ventricular arrhythmia), and these linkage data therefore suggest that in some families anomalies of potassium conductance 'intrinsic' to the myocardium may underlie the disorder. ${ }^{7}$ This cannot be true in all families, however, as the genetic heterogeneity illustrated in this report implies that Romano-Ward syndrome may have different genetic causes in different families, and this may be expressed in the phenotype. Interestingly, the Harvey-ras 1 gene has also been excluded as a candidate gene in one family with Jervell Lange-Neilsen syndrome. ${ }^{21}$ Recognition that variant forms of RomanoWard syndrome exist may permit a greater

Lod scores.

\begin{tabular}{|c|c|c|c|c|c|c|c|c|c|}
\hline \multirow{2}{*}{$\begin{array}{l}\text { Chromosomal } \\
\text { location }\end{array}$} & \multirow{2}{*}{$\begin{array}{l}\text { Locus or } \\
\text { probe }\end{array}$} & \multirow{2}{*}{$\begin{array}{l}\text { Family } \\
\text { studied }\end{array}$} & \multicolumn{7}{|c|}{ Recombination fractions } \\
\hline & & & 0 & 0.02 & $0 \cdot 04$ & 0.06 & $0 \cdot 1$ & $0 \cdot 2$ & $0 \cdot 4$ \\
\hline $6 \mathrm{p} 21.3$ & HLA & 1 & $\begin{array}{l}-10^{43} \\
-10^{43}\end{array}$ & $\begin{array}{l}-5 \cdot 0 \\
-0.82\end{array}$ & $\begin{array}{l}-3.48 \\
-0.55\end{array}$ & $\begin{array}{l}-2.62 \\
-0.4\end{array}$ & $\begin{array}{l}-1.59 \\
-0.23\end{array}$ & $\begin{array}{l}-0.47 \\
-0.06\end{array}$ & -0.01 \\
\hline $11 \mathrm{p} 15$ & $\begin{array}{l}\text { pUCEJ6.6 } \\
\text { pHINS310 }\end{array}$ & $\begin{array}{l}2 \\
1 \\
2 \\
1 \\
2\end{array}$ & $\begin{array}{l}-10^{43} \\
-10^{43} \\
-10^{43} \\
-10^{43}\end{array}$ & $\begin{array}{l}-4.02 \\
-4.15 \\
-5.01 \\
-6.53 \\
-3.9\end{array}$ & $\begin{array}{l}-2.77 \\
-3.82 \\
-4.68 \\
-3.01\end{array}$ & $\begin{array}{l}-0.4 \\
-2.0 \\
-3.13 \\
-3.62 \\
-2.49\end{array}$ & $\begin{array}{l}0.20 \\
-1.12 \\
-2.29 \\
-2.35 \\
-1.84\end{array}$ & $\begin{array}{l}-0.00 \\
-0.19 \\
-0.23 \\
-0.89 \\
-0.99\end{array}$ & $\begin{array}{c}0.1 \\
-1.18 \\
-0.07 \\
-0.21\end{array}$ \\
\hline
\end{tabular}


understanding of the disorder, its pathophysiology, and the prognosis for individual families.

We gratefully acknowledge the financial support of Grampian Health Board and the invaluable advice of Dr Kevin Kelly in the molecular study. We also thank Dr Alan Johnston for his helpful comments on the manuscript, and are grateful to the North East of Scotland Blood Transfusion service for the HLA typing.

1 Schwartz PJ. Idiopathic long QT syndrome: progress and questions. Am Heart f 1985;109:399-415.

2 Moss AJ. Prolonged QT-interval syndromes. $\mathcal{J} A M A$ 1986;256:2985-7.

3 Itoh S, Munemura S, Satoh H. A study of the inheritance pattern of Romano-Ward syndrome. Clin Pediatr 1982;21:20-4.

4 Melki J, Kaplan J, Lucet V, et al. Long QT (RomanoWard) syndrome: further definition of the linkage to the HLA loci. Cytogenet Cell Genet 1987;46:66

5 Giuffre RM, Hejtmancik JF, McCabe EPB, Towbin JA Long QT (Romano-Ward) syndrome: molecular genetic evidence against tight HLA linkage. Am $\mathcal{f}$ Hum Genet (Suppl) 1990;47:A180

6 Keating M, Dunn C, Atkinson D, Timothy K, Vincent GM, Leppert M. Consistent linkage of the long-OT syndrome to the Harvey ras-1 locus on chromosome 11. Am f Hum Genet 1991;49:1335-9.

7 Vincent GM. Hypothesis for the molecular physiology of the Romano-Ward long QT syndrome. 7 Am Coll Cardiol 1992;20:500-3.
8 Cross SJ, Dean JCS, Lee HS, et al. Study of left and right ventricular function in Romano-Ward syndrome $\mathrm{Br}$ Heart $\mathcal{f}$ 1993;70:266-71.

9 Linker NJ, Camm AJ, Ward DE. Dynamics of ventricular repolarisation in the congenital long QT syndromes. $\mathrm{Br}$ Heart $\mathcal{F} 1991 ; 66: 230-7$.

10 Moss AJ, Schwartz PJ, Crampton RS, Locati E, Carleen E. The long QT syndrome: a prospective international The long QT syndrome: a prosp

11 Lidereau R, Escot C, Theillet C, et al. High frequency of rare alleles of the human c-Harvey-ras-1 proto-oncogene in breast cancer patients. $\mathcal{F}$ Natl Cancer Inst 1986;77:697701

12 Bell GI, Horita S, Karam JH. A polymorphic locus near the human insulin gene is associated with insulin dependent diabetes mellitus. Diabetes 1984;33:176-83

13 Ott J. A simple scheme for the analysis of HLA linkages in pedigrees. Ann Hum Genet 1979;42:255-7.

14 Shaw TRD. Recurrent ventricular fibrillation associated with normal QT intervals. $Q$ f Med 1981;50:451-62.

15 Rutter N, Southall DP. Cardiac arrhythmias misdiagnosed as epilepsy. Arch Dis Child 1985;60:54-70.

16 Tobe TJM, del Langen CDJ, Bink-Boelkens MTE, et al. Late potentials in a bradycardia-dependent long QT syndrome associated with sudden death during sleep. $\mathcal{J}$ Am Coll Cardiol 1992;19:541-9.

17 Jervell A, Lange-Neilsen F. Congenital deaf mutism, prolonged QT interval, and sudden death. Am Heart $\mathcal{f}$ 1957;54:59-68

18 Reardon W, Lewis N, Hughes HE. Consanguinity, cardiac arrest, hearing impairment, and ECG abnormalities: counselling pitfalls in the Romano-Ward syndrome. $f$ Med Genet 1993;30:325-7.

19 Weitkamp LR, Moss AJ. The long QT (Romano-Ward) syndrome locus, LQT, is probably linked to the HLA loci. Cytogenet Cell Genet 1985;40:775.

20 Kerem B, Benhorin J, Kalman YM, et al. Evidence for genetic heterogeneity in the long QT syndrome. Am f Hum Genet 1992;51:A192.

21 Jeffery S, Jamieson R, Patton MA, Till J. Long QT and Harvey-ras. Lancet 1992;339:255. 